\title{
Catering Entrepreneurship Opportunities Open to Women for Wealth Creation and Sustainable Development in Nigeria
}

\author{
Augustina Oladokun \\ http://dx.doi./org/10.4314/ujah.v21i4.13
}

\begin{abstract}
Breaking away from the shackles of unemployment and ridicules of poverty is the dream of every individual and every nation. This paper on catering entrepreneurship opportunities open to women for wealth creation and sustainable development in Nigeria is very timing considering the weight of hunger, anger and illnesses in many homes in Nigeria due to poverty. Women are nation builders but unfortunately, many are unemployed. For economic development and sustainability, women who are nation builders need to strive hard to create wealth and generate income. This paper looked at the concept of wealth, wealth creation and opportunities open to women in catering business ventures for survival. Looking at the strategies stimulating women participation in catering wealth creation, nonformal education and extension services among others were highlighted. It was suggested that in the creation of wealth, money must be wisely spent and other principles of money management strictly adhered to.
\end{abstract}

Keywords: Wealth, wealth creation, catering, entrepreneurship, and entrepreneurship opportunities

\section{Introduction}

Nigeria is a country with lots of economic problems. The economic problems can be witnessed in the existence of unemployment, poverty, hunger and low standard of living in homes. The present situation has occasioned increased awareness of the need for self 
employment and self-reliance (Anele, 2004). A means to selfemployment and self-reliance is the existence of entrepreneurship.

Entrepreneurship is the ability to set up a business enterprise as different from being employed. According to Ogbene (2006), entrepreneurship is a major pivot of industrialization development and wealth creation that involves the acquisition of skills, ideas and managerial abilities necessary for personal self-reliance. Iromaka (2005) noted that individuals and persons who undertake the risk of investing in creating, founding, establishment, management and operation of business enterprises do that for the purpose of profitability, growth and growth development. Ihekoronye (2006) is of the opinion that an entrepreneur should be self-confident, selfreliant, innovative and creative, hardworking and be able to take reasonable risks from financial investments to marketing. Onwuchekwa (1993) noted that an entrepreneur is an initiator of an economic activity in a free enterprise system especially in services of economic activities, which comprises production and distribution of goods and services. Women entrepreneurs are women that participate in total entrepreneurial activities who take the risk involved in combining resources together in a unique way so as to take advantage of the opportunities identified in their immediate environment through production of goods and services (Nwolisa and Anyakoha, 2014) Women naturally according to Ihekoronye (2006) have been found to have strong inclination for business and wealth creation. One major strategy for eradicating or reducing poverty and disease is to create wealth through job creation, investment, entrepreneurship and industrial development.

\section{The Concept of Wealth}

Wealth is a collection of things limited in supply transferable and useful in satisfying human desires. Scarcity is a fundamental factor for wealth. When a desirable or valuable commodity (transferable 
goods and skills is abundantly available to everyone, the owner of the commodity will possess no potential wealth. But when a valuable or desirable commodity is in scare supply, the owner of the commodity will possess great potential for wealth. Onwa (1999) sees wealth as having money and possessions in excess. She added that the excess possessions enable the family to achieve goals and live happily. Wealth is an important resource to the family and should be protected. The protection of valuable assets of the family against misfortune or destruction is a plan towards wealth creation. Miller (1995) maintained that a complete concept of wealth would include tangible objects such as buildings, machinery and vehicles (all non- human wealth) as well as people who have skills, knowledge, initiative, talents etc (i.e. human wealth). Zaid (2015) enumerate the following as types of wealth:

- Financial wealth (money)

- Social wealth (status)

- Time wealth (freedom)

- Physical wealth (health)

In this write up, financial wealth will be discussed as it relates to catering opportunities and job creation. Catering business is an occupation that brings and generates income for the family and promotes their wellbeing. When goals are set by the family, income generated through job creation go a long way in accomplishing set goals. Nwabah and Iyere (2006) opined that wealth creation is the ability to put aside some money on regular basis as savings and savings result from careful management of income and expenditure, so that there is something left to save for the future. With the high level of poverty in Nigeria, women catering entrepreneurship is very timing now for self-employment, self-reliance and wealth creation. Catering should prepare women for the "world of work" acting as a "shock absorber" to unemployment scourge and stress. 
The effects of poverty especially with rural women necessitated the map out of different programmes for poverty alleviation in Nigeria. Oreh (2001) stated that women are people living below poverty level, who have continued to grow in high magnitude of human suffering. National Economic Empowerment Strategies (NEEDS) is out to make Nigeria free from poverty by focusing on these four key strategies such as:

- Orientation of values

- Reduction in poverty

- Wealth creation and

- Generation of employment

Needham and Dransfield (1992) stated that all activities playing a part in providing goods and services create wealth. Wealth creation therefore to him is aimed at;

- Increasing and enhancing the growth rate of industries particularly the small and medium industries which are the engines of economic growth and development.

- Generating employment not through white-collar jobs but through entrepreneurship.

- Establishing wealth creation process that will help generate foreign direct investment through expert advice for economic reforms.

\section{Concept of Catering and Services}

Food has always been an indispensable part of entertainment right from the early days. Hardly can people travel, be accommodated or housed and be entertained without food playing a major role. Besides social setting, food plays significant role in business, political, cultural and religious ceremonial settings. It is the duty of the caterer to take good care of people by providing sumptuous nourishing foods and drinks. Catering is the business of providing food services at site 
such as a hotels, hospitals, aircrafts, cruising ships, parks, filming sites or studios, entertainment sites or event venues. Madu (2006) stated that catering business flourishes very well in rural and urban centres and satisfactory profit is made through it. Catering services involve food preparation and services for various occasions and to various classes of people. Uzoka (2013) opined that caterers prepare and cook food for boarding institutions, hotels, hospitals, parties or other entertaining occasions.

Eating out is no longer an occasional event but a way of life and the dependency on the caterer to provide the day's supply of nutrients has increased. Many businesses, office workers, factory workers, students and other people who spend part of their days away from home each day, eat at least one meal and several snacks outside the house and homes. Caterers work in hospitality industries preparing meals and drinks. There are joints established to cater for people especially travelers who eat while they embark on journeys. Fast food joints are in all nook and crannies in both rural and urban areas being marred by caterers who make brisk business.

Anozie (2009) stated that fast foods are convenience foods which help homemakers or single persons to save fuel, money, time and energy. Hospitality industry is one of the fastest growing industries in the world today. The broad meaning of the term hospitality industry refer to any group that is engaged in travel and tourism, lodging, food services, meetings, conventions and expositions, leisure and recreation, (Nwokocha, 2012).

\section{Catering Entrepreneurship Opportunities Open to Women for Wealth Creation}

Catering entrepreneurship involves an individual creating business or enterprises and undertaking specific functions to provide consumers food supply services. It provides an expanding market for business of providing varied quality food services to feed large number of people 
demanding such services. Catering job can provide the family with economic empowerment and sustainability. The self-employment sustains the family economically. Money earned should be spent with wisdom. There are varieties of entrepreneurship opportunities where women play active roles at micro level to make profit. Catering entrepreneurship in rural, semi-rural and urban settings can provide fertile ground for growth of various self-reliance opportunities for women. The involvement in catering ventures creates wealth for the family by eradicating hunger and poverty, thereby creating job opportunities for others. No one person can do the work of cooking and services all alone as it is a taskful exercise that needs the services of others.

According to Ochonogor (2009) investment opportunities open to women in catering business which create wealth are as follows:

- Special Party Meal Planning: Women caterers can team up and be hired to prepare and serve meals at special occasions. Celebrants hire caterers who are known for quality cookery skills and services in special dishes like fried, jollof, coconut and white rice dishes, moi-moi, barbecued meats, fish, local and foreign salads, ethnic and cultural dishes and soups as accompaniments.

- Bread Production: Freshly baked bread such as plain, wheat, buttered, dinner rolls can be baked and sold to consumers at affordable prices. Bread is eaten any time of the day and almost all families can afford it irrespective of their social economic status as they are produced in different sizes.

- Confectionary Making: cakes and pastries made into meat and fish pies, doughnuts, chin-chin, puff-puffs, buns, eggs rolls, sausage are produced from flour for consumers. These are snacks eaten at work and on journeys to sustain hunger. They are cheap and affordable. 
- Beverages Services: A variety of drinks can be prepared with local ingredients that are nourishing and refreshing and are in high demand today. The drinks are not only nourishing and refreshing but also energizing, medicinal and delicious especially when sparingly chilled. Such drinks are zobo, kunu-zaki, soya milk, herbal teas, tiger nut drinks etc. Women entrepreneurs are now into the production of some of these drinks that are sold in parks, markets, fast food joints, in events for the generation of income for the family.

- Fast Food Production: Some caterers operate on small scale eateries where customers come to eat. Some consumers buy their foods and take them away for consumption in their homes and offices. This is a very lucrative business venture as travelers also eat as they journey. The foods include rice of all kinds, pounded yam, amala, akpu, eba, starch with accompanying soups such as egusi, ogbono, bitter leaf, okro, edikiako, ewedu depending on the locations. Pap and akara, pepper soups, beans and moi-moi are also sold. Noodles, shawama are becoming popular especially in semi-urban and urban areas for youths. At these joints, some consumers prefer to eat, drink and go away.

\section{Strategies for stimulating Women Participation in Catering Entrepreneurship}

Catering is a lucrative and wealth creation venture for women to generate income to support their husbands and children in accomplishing their goals. It is interesting to note that there are male caterers in business today. Women need to be empowered with catering skills for sustainable growth and economic development. Nigeria economy is dwindling and her citizens are struggling to survive, women should be inspired, motivated and empowered to take up catering business as occupation. As food is the basic need of man, everyone needs it for survival and happiness, because a hungry man is 
an angry man. Ochonogor (2009) stated that important machineries should be put into place to assist rural women to identify appropriate catering options for making extra income where a job already exist. Koko and Ikpesu (2006) observed that women can be better entrepreneurs if given proper education and supports because they posses traits that can make them successful in business. It is therefore necessary to highlight appropriate strategies that should be employed towards stimulating women participation in catering entrepreneurship for sustainable economic development. The following will bring success to women in catering ventures:

\section{- Non-formal Education}

Non-formal education facilities such as women development centres should be equipped for skill acquisitions in catering and other ventures like sewing, bead-making, gardening and soap making. Igba and Igba (2007) is of the opinion that households create wealth through engagement in agriculture to make more money and through the teaching of skills in cookery and baking for income generation.

\section{- Extension Services}

Extension agents and their services will go a long way in impacting knowledge to women especially those in the rural environment. Home Economic extension workers are experts who are skilled in various areas of their specialization. Those who are trained in food and nutrition will be of upmost help to women in catering business.

\section{- Adult Education}

Government can organize adult education programmes and classes for women through such agencies as the Ministry of Women Affairs and Social Welfare and National Directorate of Employment all in her bid to eradicate extreme poverty and employment creation. Skills acquisition activities can be integrated into this programmes to equip 
women with saleable skills. Amachina and Nnadozie (1995) noted that if a skill is worth acquiring, it is worth using as a tool for selfemployment.

\section{- Funding}

Money plays a very big role in setting up a business. Lack of opportunities for financial backings has been observed to be a major factor in women's non-participation in business. Sambo (2001) maintained that most institution like banks and other financial agencies are not usually willing to give assistance to investors because of lack of collateral facilities. Credit and loan facilities from government and private finance institutions hinder women in business ventures. Women need to be assisted to obtain credit facilities to step up their businesses for income generation and poverty eradication.

\section{Factors Militating against Wealth Creation}

There are many factors that can hinder and hamper wealth creation for households. The factors are:

\section{- Impulse buying}

Impulse buying is the purchase of items without real need for them. Impulse buying affects wealth creation within households. It takes away money that would have been used for family needs for unimportant items. According to Anyakoha and Eluwa (1999), impulsive buying is the act of buying a good or article on the "spur" of the moment without thinking whether one really needs the item. This buying or spending is not budgeted for. Self-service practised in supermarkets, with the alternative packaging and display designs often encourage impulsive buying. Such buying is often unwise and expensive. Ukpore (2006) maintained that consumer economists do not encourage impulse buying as it often wrecks a well thought out budgets and may lead to financial difficulties. The main reason for going into business is to make profit and it would be stupid of an 
entrepreneur who needs money to start, establish and improve on the growth of his or her business to waste money meant for his or her business.

\section{- Lack of Budgeting}

According to Anyakoha and Eluwa (1999) budget is the plan for future expenditures and represents the first step in money management. Budgeting helps a person to decide how to spend and how much to save for a given period of time. Any money wasted is a loss to the family and any money saved is for the good of the family. An entrepreneur grows by making good budget of what to spend and how to spend money. Nwankwo (2009) maintained that economic growth and sustainability depends among other things on adequate family resources management. Money spent on emulative buying of items not immediately needed in the family may be a waste of hard earned income. Sambo (2001) opined that lack of budget can lead to misunderstanding and conflict among family members as it takes away money earmarked for other purposes. A good budget plan helps a household and helps in business growth by spending money within budgets. Olotu (2006) is of the opinion that having a financial plan or budget is powerful, compelling, inspiring and motivating.

\section{Principles of Money Management for Wealth Creation}

Nwankwo (2009) stated that people work hard to get money and more money through gainful-employment, self-employment, business etc. She added that money is a resource that is hard to earn and should be wisely used and managed for specific needs of the family. For sustainability, money earned should be spent with wisdom following steps for effective shopping and buying techniques which should include knowing where to buy, how to buy, when to buy and what to buy at each given time (Osuala, 2000). To create wealth, there must be principles to guide money management. Money management is an 
organized process of allocating or using money to achieve specific goals that are usually purchased with money. The goals represent our needs. Anyakoha and Eluwa (1999) enumerated the following principles as guidelines for money management and they are:

- Ensure that your expenditure is within the limit of your income and do not spend more than your income.

- Establish priorities among goals that is, determine which goals are most important and need to be attained early.

- Mark a budget on how to use the available income for achieving the goals, that is, a plan for emergence such as accidents, illness etc.

- Keep good record about any money spent. Keep a file for all receipts such as for electricity bill, telephone bill, house rent, school fees and purchase of household equipment.

- Determine the income available to you or the family for achieving the goals and consider the direct and indirect sources of income.

- Control all money management activities and try to eliminate waste by spending only on planned goals. Avoid impulsive buying, compare prices of commodities before buying and study available information on labels before buying.

It is of utmost importance to be disciplined with finance. To create wealth, the entrepreneur must be totally free from financial turmoil and worries which is one of the chief causes of suffering within the majority of people's lives.

\section{Conclusion}

Entrepreneurship is the gateway for building women's economic capacity. Women who are nation builders are encouraged to strive towards economic growth and eradication of poverty. Women should be empowered to take up numerous catering entrepreneurship opportunities to alleviate poverty in their various homes for the 
survival of the nation. Consequently, it is suggested that fund (loan) should be made available to women to establish various businesses of their choice in catering. Such loan must not be made too difficult for repayment. Unplanned expenditure should be avoided as this may cripple the business so established.

\section{Augustina Oladokun}

Home Economics Department

College of Education, Agbor

ttoladokun@yahoo.com

\section{References}

Amaechina, H.O. and Nnadozie, B.M. (1995) Entrepreneurship Concept of Small Business Management. Ekuolobia: Theo Onwuka and Sons Publishers.

Anele, E. (2004) Towards Enhancing The Managerial Competencies of Entrepreneurs of Technology Based Enterprise. Journal of Home Economics Research 5(3) 83-87.

Anozie, G.O. (2009) Purchasing Practices of Fast Food Industries in Anambra State. Journal of Home Economic Research 11 (1011).

Anyakoha, E.U. and Eluwa, M. (1991) Home Management for Schools and Colleges. Ibadan: Inter Printers Ltd.

Anyanele, B.U. (2006) Home Administration. Onitsha: Umeh publishers.

Hornby, A.S. (2000) Advanced Learner's Dictionary. New York: Oxford University Press Wchmeier.

Igba, C.E. and Igba D.I,. (2007) Strategies for Enhancing Wealth Creation in Families in Abakaliki Municipal Area of Ebonyi State. Journal of Home Economics Research. 8(182-189). 
Oladokun: Catering Entrepreneurship Opportunities Open to Women for Wealth Creation and Sustainable Development in Nigeria

Ihekoronye, C.N. (2006) Women Entrepreneurship Challenges, Contribution to Family Living Growth. Journal of Home Economics Research (Special Edition) 7 (24-27).

Iromoka, S. (2005) Business Education At A Glance. Lagos: Tee Polishers.

Koko, M. N. and Ikpesu, O. C. (2006) Entrepreneurship as a Gateway for Building Women Economic Capacity in Nigeria. African. Journal of Education and Development Studies 1(3) (112119).

Miller, R.L. (1998) Economics Today. New York: Harper and Row Publishers.

Morgan, N.J. (1974) Supervision and Management of Quality Food Preparation: Principles and Procedure California: McCutchan Publishing Cooperation.

Needlham, D. and Grandfield, R. (1992) Business financing. London: Heine Mann publishers.

Nwabah, N. and Iyere, O.F. (2006) Youth Economic Security Through Financial Management Education: Role of Home Economics Education. Journal of Home Economics Research. Special Education.

Nwankwo, J.N. (2009) Meeting the Economic Sustainability of The Family Through Home Economics. Nigerian: Journal of Home Economics 1(1).

Nwokocha, F. (2012) Hospital Industry Today. Ibadan: Omotayo Publishers.

Nwolise, C.U. and Anyakoha, C.N. (2014) Empowerment Strategies for Female Entrepreneurs and Role of Finance Institution. Journal of Home Economics Research 21 198-203.

Nzelibe, C.G.O. (1996) Entrepreneurship and Management of Small Scale Business. Enugu: Optimal Publishers.

Ochonogor, E.C. (2009) Catering Entrepreneurship Opportunities Open to Rural Women For Wealth Creation. Journal of 
Vocational Education on Issues and Research in Vocational Education 2(1) 221-226.

Ogbene, A.E. (2006) Home Economics for Self-reliance in a Depressed Economy: An Entrepreneurial Initiative, Journal of Home Economics Research 7 Special Edition 107-112

Okafor, J.O. (2009) Functional Vocational Education. A Veritable Tool For Economic Empowerment and Poverty Eradication in Nigeria. Journal of Vocational and Technical Education 7 (2)

Oladeji, F. (1999) Wealth Creation and Family. Ibadan: University Press.

Olotu, B. (2005) Think, Learn, Take Action and Grow Rich. Practical Options for Wealth Creation. Lagos: Nissi Entrepreneurship and Investment Initiative Limited.

Ombagadu, A. E. and Yusuf, T.A. (2007) The Role of Home Economics in Developing Entrepreneurial Activities in Rural Areas of Nasarawa State. Journal of Home Economics Research 8(50-56).

Onuka, A. U. and Olaitan, S.O. (2007) Entrepreneurship Skills required for Economic Empowerment of Youths in Broiler Production. Journal of Home Economics Research 8(13-16).

Onwa, S.O. (1999) Wealth Creation and Developing Nations. Lagos: Ojo Press.

Onwuchekwa, C.I (1993) Managing Small Business Organization. An Organizational Design Analysis. Awka: Goshen Printing and Publishing Company.

Oreh, C. I. (2001) Democratic Participation of Rural Women in Community Development and Poverty Alleviation and Sustainable Development in Research Imperative and Challenges for Home Economics in Nigeria.

Osuala, E. C. (2000) Principles and Practice of Small Business Management in Nigeria: A Didactic Approach, Nsukka: Fulladu Publishers. 
Oladokun: Catering Entrepreneurship Opportunities Open to Women for Wealth Creation and Sustainable Development in Nigeria

Sambo, B. I. (2001) Establishing Small Business: A Step Towards Self-Reliance. Journal of Technical Teacher Education . I (131-136).

Scott, R.H. and Nigro, N. (1997) Principles of Economics. New York: Macmillan Publisher

Ukpore, B.A. (2006) Fundamentals of Consumer Education. Ibadan: Spectrum Book Limited.

Umezurike, N.A. (2006) Repackaging Women Education for National Development. Journal of Teacher Education and Teaching 2(3) (110-115).

Uzoka, F.A. (2013) Home Economic Methodology for Colleges and Universities. Enugu: Chembas Communication. 